\title{
Estimation of foetal birth weight clinically and sonographically and its correlation with its actual birth weight: a prospective and comparative study
}

\author{
Preeti Bajaj, Gunvant K. Kadikar*, Medha Kannani, Manoj Bhatt, Shivani Shah
}

Department of Obstetrics and Gynecology, Government Medical College, Bhavnagar, Gujarat, India

Received: 10 May 2017

Accepted: 03 June 2017

*Correspondence:

Dr. Gunvant K. Kadikar,

E-mail: preetib199@gmail.com

Copyright: () the author(s), publisher and licensee Medip Academy. This is an open-access article distributed under the terms of the Creative Commons Attribution Non-Commercial License, which permits unrestricted non-commercial use, distribution, and reproduction in any medium, provided the original work is properly cited.

\begin{abstract}
Background: Knowledge of fetal weight in utero is vital for the obstetrician in deciding whether to deliver the fetus as well as in fixing the mode of delivery. Both low birth weight and excessive fetal weight at delivery are associated with increased risk of newborn complications during labor and the puerperium. During the last decade, estimated fetal weight has been incorporated into the standard routine antepartum evaluation of high-risk pregnancies and deliveries. Objective of present study was to assess the fetal weight in term pregnancies by Clinical and Sonographic and to compare the methods after knowing the actual weight of the baby after birth.

Methods: It is a prospective and comparative study of 200 women at term pregnancy at Sir T. Hospital, Bhavnagar, India from 2015 to 2016. Patients within 7 days from their Expected Date of Delivery were included in the study. The formulas used in this study are: Johnson's formula, Dare's formula and Hadlock's formula using ultrasound.

Results: Results vary in terms of accuracy with various methods employed for estimating the fetal weight. This study showed that Dare's Formula was the best indicator among all other methods assessed followed by Hadlock's formula by ultrasonographic method.

Conclusions: SFH measurement continues to be used in many countries on large scale because of its low cost, ease of use and need for little training as the setup for ultrasonographic evaluation is not readily available in rural setups.
\end{abstract}

Keywords: Abdominal girth, Dare's formula, Hadlock's formula, Johnson's formula, Symphysio-fundal height

\section{INTRODUCTION}

Assessment of fetal weight is a vital and universal part of antenatal care, not only in the management of labor and delivery but often during the management of high risk pregnancies and growth monitoring. ${ }^{1}$ Birth weight of an infant is the single most important determinant of newborn survival. ${ }^{1,2}$ Both low and excessive fetal weights at delivery are associated with an increased risk of newborn complications during labor and puerperium. Limiting the potential complications associated with the birth of both small and excessively large foetuses requires that accurate estimation of fetal weight occurs before decision to deliver is made. ${ }^{3}$

On the other hand, fetal macrosomia is associated with more maternal and fetal complications at the time of birth than other neonatal weight groups. ${ }^{4}$ Maternal complications include increased caesarean rate, higher risk of injury to the genital tract, uterine rupture, as well as postpartum hemorraghe. ${ }^{5}$ The two main methods for predicting birth weight in current obstetrics are clinical 
and ultrasonographic methods. ${ }^{6,7}$ In developing countries, ultrasonography may be unavailable or may not be affordable by patients. That is why measurement of fundal height using inexpensive and easily available nonelastic tapes has been recommended as a means of assessing birth weight in low-resource countries.

The present study aimed at estimation of fetal birth weight clinically and sonographically and compare them with actual birth weight after delivery of fetus.

\section{METHODS}

The present study was a prospective comparative study done in between in the year 2015-2016 in Department of Obstetrics and Gynaecology, Sir Takhtsinhji Hospital, Bhavnagar. The study population consisted of 200 patients which were randomly selected, who were admitted in Gopnath Maternity Home at Sir T. Hospital, Bhavnagar

\section{Inclusion criteria}

- Term pregnancies 37-42 weeks

- $\quad$ Singelton pregnancy

- Vertex presentation

- Women should deliver within 3 days of estimation.

\section{Exclusion criteria}

- Oligohydramnios, polyhydramnios

- Multiple pregnancies

- Malpresentation

- Congenital abnormalities of foetus

- Intrauterine foetal death

- Premature rupture of membrane

- Pregnancy with uterine fibroid or any abdominal mass

- Placenta previa.

Patients admitted in the Gopnath Maternity Home for various reasons were taken in study after the satisfying the inclusion and exclusion criteria. A preliminary history taking, thorough general examination and obstetric examination was taken for study and informed consent for the study was taken.

Patients were asked to lie flat on their back with thighs slightly flexed after emptying bladder. Symphysio-fundal height and abdominal girth measurement were taken in between contractions with flexible elastic standard measuring tape. Estimated fetal weight was calculated according to Johnson's formula and Dare's formula.

\section{Johnson's formula}

Foetal weight in $\mathrm{gm}=155 *$ (fundal height in $\mathrm{cm}-\mathrm{K})$
$\mathrm{K}=11$ (foetal head at plus station), $\mathrm{K}=12$ (foetal head at zero station), $\mathrm{K}=13$ (foetal head at minus station).

\section{Dare's formula}

Foetal weight in $\mathrm{gm}=$ fundal height in $\mathrm{cm} *$ abdominal girth in $\mathrm{cm}$.

For sonographic method: They were analyzed for estimated fetal weight by Hadlock's formula (inbuilt) on ultrasonography machine.

Patients were followed up till delivery and actual birth weight measured. Their data was taken as per performa.

\section{Statistical analysis}

Data obtained was tabulated and analysed using percentages, mean, averages to obtain the percentage errors, average errors of each clinical formula and sonography, after that the mean average error in all cases studied. Standard deviation was calculated using mean. Finally, the correlation coefficient " $r$ " were calculated to know association between actual birth weight and weight decided by clinically and sonographically.

\section{RESULTS}

In this study, maximum group of the patients were observed in the 20-25year age group $(60.5 \%)$.

Table 1: Maternal age distribution ( $\mathrm{N}=\mathbf{2 0 0})$.

\begin{tabular}{|lll|}
\hline Age (years) & No. of patients & $\%$ \\
\hline $18-20$ & 5 & 2.5 \\
\hline $20-25$ & 121 & 60.5 \\
\hline $26-30$ & 49 & 24.5 \\
\hline$>30$ & 17 & 8.5 \\
\hline
\end{tabular}

In this study, out of 200 women $34.5 \%$ were primigravida and $65.5 \%$ multigravidas. Parity distribution is comparable to the Bhandary et al.

Table 2: Maternal parity distribution $(\mathrm{N}=200)$.

\begin{tabular}{|lll|}
\hline Parity & Primigravida & Multigravida \\
\hline Anupurna K & $50 \%$ & $50 \%$ \\
\hline Bhandary A et al & $45 \%$ & $55 \%$ \\
\hline Present study & $69(34.5 \%)$ & $131(65.5 \%)$ \\
\hline
\end{tabular}

In this study, $70 \%$ of patients delivered vaginally where as $30 \%$ patients had undergone LSCS for various indications.

The cases were distributed as per the birth weight of babies into five groups. In India, average birth weight $2500-3000$ gm. In this study, 2501-3000gm group had maximum distribution $(46.5 \%)$ of cases compared to other groups. So, birth weight according to weight in gm 
in present study is comparable to Bandhary et al and Anupurna K et al.

Table 3: Mode of delivery $(\mathrm{N}=200)$.

\begin{tabular}{|llll|}
\hline $\begin{array}{l}\text { Type of } \\
\text { delivery }\end{array}$ & $\begin{array}{l}\text { Normal } \\
\text { delivery }\end{array}$ & Instrumental & LSCS \\
\hline Present study & $85 \%(170)$ & - & $\begin{array}{l}15 \% \\
(30)\end{array}$ \\
\hline $\begin{array}{l}\text { Bhandary A } \\
\text { et al }\end{array}$ & $70 \%$ & $19.5 \%$ & $10.5 \%$ \\
\hline $\begin{array}{l}\text { Anupurna K } \\
\text { et al. }\end{array}$ & $86 \%$ & - & $14 \%$ \\
\hline
\end{tabular}

The proportion of Low Birth weight $(<2500)$ was found to be high with maternal weight group ranging from 40$55 \mathrm{~kg}(66 \%)$ compared to women with increased weight in the range of $56-70 \mathrm{~kg}(25 \%)$.
It can be observed that the birth weight increases along with the maternal weight. So, results of present study are comparable to study by Anupurna K.

Table 4: Distribution of cases according to birth weight $(\mathrm{N}=\mathbf{2 0 0})$.

\begin{tabular}{|llllll|}
\hline $\begin{array}{l}\text { Birth } \\
\text { weight } \\
\text { in GM }\end{array}$ & $<2000$ & $\begin{array}{l}2000- \\
2500\end{array}$ & $\begin{array}{l}2501- \\
3000\end{array}$ & $\begin{array}{l}3001- \\
3500\end{array}$ & $>3500$ \\
$\begin{array}{l}\text { Bhandary } \\
\text { A et al }\end{array}$ & $7 \%$ & $\begin{array}{l}22.5 \\
\%\end{array}$ & $54 \%$ & $15 \%$ & $1.5 \%$ \\
\hline $\begin{array}{l}\text { Anupurna } \\
\text { K et al. }\end{array}$ & & $15 \%$ & $46 \%$ & $35 \%$ & $4 \%$ \\
\hline $\begin{array}{l}\text { Present } \\
\text { study }\end{array}$ & $3 \%$ & $21 \%$ & $46.5 \%$ & $24.5 \%$ & $5 \%$ \\
& $(6)$ & $(42)$ & $(93)$ & $(49)$ & $(10)$ \\
\hline
\end{tabular}

Table 5: Birth weight in relation to maternal weight.

\begin{tabular}{|c|c|c|c|c|c|c|c|}
\hline \multirow{2}{*}{$\begin{array}{l}\text { Maternal } \\
\text { weight in kg }\end{array}$} & \multicolumn{5}{|c|}{ Birth weight in gm } & \multirow{2}{*}{$\begin{array}{l}\text { Present } \\
\text { study }\end{array}$} & \multirow{2}{*}{$\begin{array}{l}\text { Anupurna } \mathrm{K} \\
\text { et al. }\end{array}$} \\
\hline & $<2000$ & $2000-2500$ & 2501-3000 & 3001-3500 & $>3500$ & & \\
\hline $40-55$ & 4 & 28 & 26 & 12 & 2 & $72(36 \%)$ & $40 \%$ \\
\hline $56-70$ & 1 & 11 & 50 & 27 & 5 & $94(47 \%)$ & $60 \%$ \\
\hline$>70$ & 1 & 03 & 17 & 10 & 3 & $34(17 \%)$ & - \\
\hline Total & 6 & 42 & 93 & 49 & 10 & 200 & \\
\hline
\end{tabular}

Table 6: Birth weight in relation to gravida.

\begin{tabular}{|llllllll|}
\hline Gravida & Birth weight in gm & & & & Present & $\begin{array}{l}\text { Anupurna K } \\
\text { et al. }\end{array}$ \\
\hline 1 & $<\mathbf{2 0 0 0}$ & $\mathbf{2 0 0 0 - 2 5 0 0}$ & $\mathbf{2 5 0 1 - 3 0 0 0}$ & $\mathbf{3 0 0 1 - 3 5 0 0}$ & $\mathbf{> 3 5 0 0}$ & study & 50 \\
\hline 2 & $2(33.3 \%)$ & $12(28.5 \%)$ & $33(35.5 \%)$ & $18(36.7 \%)$ & $4(0.4 \%)$ & 69 & 30 \\
\hline 3 & $2(33.3 \%)$ & $15(35.7 \%)$ & $30(32.2 \%)$ & $15(30.6 \%)$ & $4(0.4 \%)$ & 66 & 15 \\
\hline 4 & $2(33.3 \%)$ & $12(28.6 \%)$ & $21(22.6 \%)$ & $11(22.4 \%)$ & 0 & 46 & 5 \\
\hline$>4$ & 0 & $3(7.1 \%)$ & $6(6.4 \%)$ & $4(8.2 \%)$ & $2(0.2 \%)$ & 15 & - \\
\hline Total & 0 & 0 & $3(3.2 \%)$ & $1(2.0 \%)$ & 0 & 04 & 100 \\
\hline
\end{tabular}

Table 7: Average error in various fetal weight groups by various methods.

\begin{tabular}{|c|c|c|c|c|c|c|c|c|}
\hline \multirow[t]{2}{*}{ Method } & \multicolumn{5}{|c|}{ Birth weight in gm } & \multirow{2}{*}{$\begin{array}{l}\text { Present } \\
\text { study }\end{array}$} & \multirow{2}{*}{$\begin{array}{l}\text { Bhandary } \\
\text { A et al }\end{array}$} & \multirow{2}{*}{$\begin{array}{l}\text { Anupurna } \\
\mathrm{K} \text { et al. }\end{array}$} \\
\hline & $<2000$ & $2000-2500$ & 2501-3000 & 3001-3500 & $>3500$ & & & \\
\hline $\mathrm{N}$ & 6 & 42 & 93 & 49 & 10 & 200 & 200 & 100 \\
\hline $\begin{array}{l}\text { Johnson's } \\
\text { formula }\end{array}$ & 488.33 & 337.52 & 284.54 & 215.24 & 359.20 & 336.96 & 292.51 & 121.2 \\
\hline $\begin{array}{l}\text { Dare's } \\
\text { formula }\end{array}$ & 340.33 & 198.88 & 170.65 & 193.63 & 204.20 & 221.53 & 224.37 & - \\
\hline $\begin{array}{l}\text { Hadlock's } \\
\text { formula }\end{array}$ & 252.66 & 257.92 & 195.61 & 203.24 & 218.80 & 225.64 & 299.11 & 42.91 \\
\hline
\end{tabular}

The cases within the birth weight (2000-2500gm) were observed more in second gravida $(35 \%)$ followed by third gravida (28.6\%). Birth weight according to Gravida status in this study is almost comparable to the study by Anupurna K et al.
Average error in fetal weight group is given in Table 7.

Average error $=1 / \mathrm{n} \sum$ \{actual birth weight-estimated birth weight 
Where, $n=$ no of cases, Average error in all groups except $<2000$ gm was least with Dare's formula, closely followed by Hadlock's formula. Average error in <2000gm weight group was least with Hadlock's formula. Present study is comparable to study by Bhandary et al.

Table 8: Maximum error in various fetal weight groups by various methods.

\begin{tabular}{|c|c|c|c|c|c|c|c|c|}
\hline \multirow{2}{*}{ Method } & \multicolumn{5}{|c|}{ Birth weight in gm } & \multirow{2}{*}{$\begin{array}{l}\text { Present } \\
\text { study }\end{array}$} & \multirow{2}{*}{$\begin{array}{l}\text { Bandhary } \\
\text { A et al }\end{array}$} & \multirow{2}{*}{$\begin{array}{l}\text { Anupurna } \\
\mathrm{K} \text { et al }\end{array}$} \\
\hline & $<2000$ & 2000-2500 & 2501-3000 & 3001-3500 & $>3500$ & & & \\
\hline $\mathrm{N}$ & 6 & 42 & 93 & 49 & 10 & 200 & 200 & 100 \\
\hline $\begin{array}{l}\text { Johnson's } \\
\text { formula }\end{array}$ & 790 & 840 & 901 & 732 & 737 & 800 & 534.2 & 600 \\
\hline $\begin{array}{l}\text { Dare's } \\
\text { formula }\end{array}$ & 450 & 550 & 566 & 480 & 507 & 510.6 & 714 & - \\
\hline $\begin{array}{l}\text { Hadlock's } \\
\text { formula }\end{array}$ & 400 & 590 & 517 & 450 & 407 & 472.8 & 647.4 & 563 \\
\hline
\end{tabular}

Table 9: Ranges of percentage error in the various methods.

\begin{tabular}{|c|c|c|c|c|}
\hline Percentage error & & Johnson's formula & Dare's formula & Hadlock's formula \\
\hline \multirow{3}{*}{ Up to $5 \%$} & Present study & 35.5 & 50 & 34 \\
\hline & Bandhary A et al & 17 & 33.5 & 27.5 \\
\hline & Anupurna $\mathrm{K}$ et al & 22 & & 65 \\
\hline \multirow{3}{*}{ Up to $10 \%$} & Present study & 55.5 & 68 & 67 \\
\hline & Bandhary A et al & 41 & 67 & 62 \\
\hline & Anupurna $\mathrm{K}$ et al & 54 & & 88 \\
\hline \multirow{3}{*}{ Up to $15 \%$} & Present study & 73 & 86 & 87 \\
\hline & Bandhary A et al & 63.5 & 85.5 & 85.5 \\
\hline & Anupurna $\mathrm{K}$ et al & 87 & & 97 \\
\hline \multirow{3}{*}{ Up to $20 \%$} & Present study & 80.5 & 94.5 & 94 \\
\hline & Bandhary A et al & 79.5 & 94 & 96.5 \\
\hline & Anupurna $\mathrm{K}$ et al & 98 & & 99 \\
\hline \multirow{3}{*}{ Up to $25 \%$} & Present study & 91.5 & 98 & 98 \\
\hline & Bandhary A et al & 89.5 & 96.5 & 96.5 \\
\hline & Anupurna $\mathrm{K}$ et al & 100 & & 100 \\
\hline
\end{tabular}

Maximum error was most marked with Johnson's formula and least with Hadlock's formula.

Maximum error with fetal weight 200-2500g was least with Dare's formula. Present study is comparable to Bhandary et al. Percentage error of method was calculated by using the formula

Percentage error $=\mathrm{x} / \mathrm{y} * 100$

Where $\mathrm{x}=$ error in gm, $\mathrm{y}=$ actual birth weight in gm,

As seen in Table $8,86 \%$ of the cases fell within 15 percentile error of birthweight by both Dare's formula and Hadlock's formula. As compared to that only $73 \%$ of cases fell within 15 percentile error of birthweight by Johnson's formula.

So, this study is more comparable to the study by Bhandary et al than the study by Anupurna K et al.
Table 9: Standard deviation of prediction error.

\begin{tabular}{|l|l|l|}
\hline $\begin{array}{l}\text { Method } \\
\text { Johnson's formula }\end{array}$ & $\begin{array}{l}\text { Present study } \\
\text { Bandhary A et } \\
\text { al }\end{array}$ \\
\hline Dare's formula & 404.68 & 309.98 \\
\hline Hadlock's formula & 400.71 & 272.66 \\
\hline
\end{tabular}

Standard deviation $=\sqrt{ } \sum(\mathrm{x}-\mathrm{y})^{2} / \mathrm{n}$,

Where, $\mathrm{x}=$ actual birth weight, $\mathrm{y}=$ estimated birth weight.

Standard deviation of the prediction error by different method: $400.71 \mathrm{gm}$ by Hadlock's formula closely followed by Dare's formula followed by Johnson's formula.

Results of this study by standard deviation of prediction error is comparable to the study by Bhandary et al. 
Table 10: Comparison of different methods.

\begin{tabular}{|llll|}
\hline $\begin{array}{l}\text { Average } \\
\text { error }\end{array}$ & $\begin{array}{l}\text { Standard } \\
\text { deviation }\end{array}$ & $\begin{array}{l}\text { Confidence } \\
\text { interval }\end{array}$ \\
\hline $\begin{array}{l}\text { Johnson's } \\
\text { formula }\end{array}$ & 336.96 & 405.04 & $\begin{array}{l}280.4819 \text { to } \\
393.43\end{array}$ \\
\hline $\begin{array}{l}\text { Dare's } \\
\text { formula }\end{array}$ & 221.53 & 404.68 & $\begin{array}{l}165.0519 \text { to } \\
278.008\end{array}$ \\
\hline $\begin{array}{l}\text { Hadlock's } \\
\text { formula }\end{array}$ & 225.64 & 400.71 & 169.7256 to \\
\hline
\end{tabular}

Confidence interval $=$ mean $\pm 2 \mathrm{SE}$,

Where, $\mathrm{SE}=\mathrm{s} / \sqrt{ } \mathrm{n}, \mathrm{s}=$ standard deviation, $\mathrm{n}=$ no of cases

Based on average error in weight, Dare's formula showing near average of actual weight as compared to other formulas. So, Dare's formula is more reliable than other formula. Considering the Degree of variation based on average error, standard deviation and their Confidence interval, Dare's formula and Hadlock's formula are almost comparable. No significant variation has been observed in both the formulas.

\section{DISCUSSION}

Both fetal macrosomia and intrauterine growth restriction increase the risk of perinatal morbidity and mortality and of long term neurologic and developmental disorders. ${ }^{8}$

Accurate prediction of fetal weight has been of great interest in obstetrics. As fetal weight cannot be measured directly, it must be estimated from fetal and maternal anatomical characteristics.

For the ultrasonographic method, our results are also consistent with what have been previously observed that the mean absolute percentage error of predicted birthweight varies from $6 \%$ to $12 \%$ of actual birthweight, and $40-75 \%$ of the estimates are within $10 \%$ of actual birthweight. ${ }^{8-10}$ The observation that, compared to actual birthweight, ultrasound overestimated low birthweight and underestimated high birthweight, has also been previously reported. ${ }^{8,11}$

The major finding from this prospective study is that clinical estimation of foetal weight is as accurate as the ultrasonographic method of estimation within the normal birthweight range. Although, while the clinical method overestimated foetal weight, our ultrasonic method underestimated it. However, when there is the case of intrauterine growth restriction (birthweight $<2,500 \mathrm{~g}$ ), both the methods overestimated birthweight, but the ultrasonic method was statistically more accurate with smaller mean errors and more estimates within $\pm 10 \%$ of actual birthweight.

Despite the differences in study design, present findings are in consonance with those reported by others that the accuracy of clinical estimation of birthweight is similar if not better than that of ultrasonic estimation. The studies by Hendrix et al. and Raman et al. showed that clinical estimation was significantly more accurate than sonographic prediction. ${ }^{12,13}$ Similar results as obtained by Sharman et al. and Titapant et al. who observed that ultrasonic estimation was more accurate only when there is low birthweight but in their own studies, both the methods underestimated birthweight by more than 400 g. ${ }^{11,14}$ Watson et al. found no significant difference between the two methods even at extremes of birthweight at term. ${ }^{15}$

Present observation implies that there is clearly a role for clinical estimation of birthweight as a diagnostic tool, suggesting that clinical estimation is sufficient to manage labour and delivery in a term pregnancy. Even in estimating weight of macrosomic foetus for making decision regarding trials of labour, there appears to be no benefit in obtaining a routine sonographic birthweight. The role for ultrasonographic estimation appears that, when clinically estimated weight suggests weight less than $<2,500 \mathrm{~g}$, subsequent sonographic estimation would yield a better prediction and would be further necessary to assess such foetuses for congenital malformation and to do the biophysical profile to determine the well-being of the foetus.

The potential limitations of the study include: (a) the subjectivity of clinical estimation, (b) use of only one sonographic model to derive estimates of foetal weight, (c) no confirmation that the formula used (Hadlocks 3 ) is universally applicable.

We regard the overestimation of foetal weight by the clinical method as a positive factor since it will enhance the sensitivity of health workers at peripheral centres if properly taught to them for earlier referral of mothers with macrosomic foetuses, thus contributing to reduction of obstructed labour and its sequelae. ${ }^{16}$

\section{CONCLUSION}

Antenatal fetal weight can be estimated clinically by using Johnson's formula and Dawn's formula and sonographically by Hadlock's formula. Despite the superiority of ultrasonography, the simple clinical method of estimation of fetal weight is of great value especially in a developing country. Thereafter for the confirmation and to rule out complications they can refer to higher centre for ultra-sonographic examination and for better management specially when they are high-risk patients. The present study indicates that among full term singleton cephalic presentation, foetal weight estimation using measuring tape is just as accurate as ultrasound estimates for prediction of actual birth weight. This simple clinical method for FEW is easy to perform. It is very useful, inexpensive, and practical tools for predicting birth weight, especially for less experienced examiner and with limited resources. 
Funding: No funding sources

Conflict of interest: None declared

Ethical approval: The study was approved by the Institutional Ethics Committee

\section{REFERENCES}

1. Ugwu EO, Udealor PC, Dim CC, Obi SN, Ozumba BC, Okeke DO et al. Accuracy of clinical and ultrasound estimation of fetal weight in predicting actual birth weight in Enugu, Southeastern Nigeria. Nigerian J Clin Prac. 2014;17(3):270-5.

2. Bajracharya J, Shrestha NS, Karki C. Accuracy of prediction of birth weight by fetal ultrasound. Kathmandu Univ Med J. 2013;10(2):74-6.

3. Kehinde OA, Njokanma OF, Olanrewaju DM. Parental socioeconomic status and birth weight distribution of Nigerian term newborn babies. Nigerian J Pediatr. 2013;40(3):299-302.

4. Westerway SC. Estimating fetal weight for best clinical outcome. Austr J Ultrasound Med. 2012;15(1):13-17.

5. Ashrafganjooei T, Naderi T, Eshrati B, Babapoor N. Accuracy of ultrasound, clinical and maternal estimates of birth weight in term women. East Mediterr Health J. 2010;16(3):313-7.

6. Ju H, Chadha Y, Donovan T, O'Rourke P. Fetal macrosomia and pregnancy outcomes. Aust N Z J Obstet Gynecol. 2009;49:504.

7. Mulik V, UshaKiran TS, Bethal J, Bhal PS. The outcome of macrosomic fetuses in a low risk primigravid population. Int $\mathbf{J}$ Gynecol Obstet. 2003;80(1):15-22.

8. Nahum G. Estimation of fetal weight - a review article last updated on 11 July 2002. Available at http://www.emedicine.com. Accessed on 28 March 2003.
9. Ratanasiri T, Jirapornkul S, Sombooporn W, Seejorn $\mathrm{K}$, Patumnakul P. Comparison of the accuracy of ultrasonic fetal weight estimation by using the various equations. J Med Assoc Thai. 2002;85:962-7.

10. Baum JD, Gussman D, Stone P. Clinical and patient estimation of fetal weight vs. ultrasound estimation. J Reprod Med. 2002;47:194-8.

11. Sherman DJ, Arieli S, Tovbin J, Siegel G, Caspi E, Bukovsky IA. A comparison of clinical and ultrasound estimation of fetal weight. Obstet Gynecol. 1998;91:212-7.

12. Hendrix NW, Grady CS, Chauhan SP. Clinical versus sonographic estimates of birth weight in term of parturients. A randomized clinical trial. J Reprod Med. 2000;45:317-22.

13. Raman S, Urquhart R, Yusof $M$. Clinical versus ultrasound estimation of fetal weight. Aust N Z J Obstet Gynecol. 1992;32:196-9.

14. Titapant V, Chawanpaiboon S, Mingmitpatanakul K. A comparison of clinical and ultrasound estimation of fetal weight. J Med Assoc Thai. 2001;84:1251-7.

15. Watson WJ, Soisson AP, Harlass FE. Estimated weight of the term fetus. Accuracy of ultrasound vs. clinical examination. J Reprod Med. 1988;33:36971.

16. Orji EO. Analysis of obstructed labour at Ife State Hospital. Sahel Med J. 2002;5:143-8.

Cite this article as: Bajaj P, Kadikar GK, Kannani M, Bhatt M, Shah S. Estimation of foetal birth weight clinically and sonographically and its correlation with its actual birth weight: a prospective and comparative study. Int J Reprod Contracept Obstet Gynecol 2017;6:3103-8. 